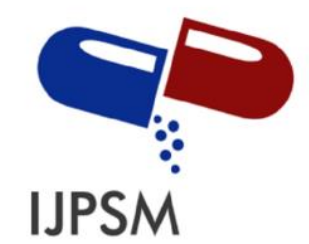

Chourasiya Vaibhav et al, Int. Journal of Pharmaceutical Sciences and Medicine (IJPSM), Vol.6 Issue. 8, August- 2021, pg. 118-133

ISSN: 2519-9889

Impact Factor: 3.426

\title{
EVALUATION OF ANALGESIC ACTIVITY OF SHOREA ROBUSTA RESINS
}

\author{
Chourasiya Vaibhav*; Sujane Sandhya; Bapna Rajendra; Gupta Namrata \\ Department of Pharmacology, Swami Vivekanand College Of Pharmacy, Indore (Madhya-Pradesh), India \\ DOI: 10.47760/ijpsm.2021.v06i08.008
}

\begin{abstract}
Shorea robusta (Sal), an important traditional Indian medicinal plant used in various ailments and rituals and the indigenous use of the resin of this plant as a medicament for treatment of various inflammatory conditions is well documented in literature. In the present study, ethanolic extract of S. robusta resin (SRE) was evaluated for its analgesic activity by making use of different central and peripheral pain models. The phytochemical studies have shown the presence of many secondary metabolites belonging to terpenoids, flavonoids, carbohydrate, lignans, phenols and sterols. Crude extracts and isolated compounds from Shorea robusta show a wide spectrum of pharmacological activities, such as anti-inflammatory, antiobesity, antibacterial, wound healing, anti-pyretic \& analgesic activities. Many studies have provided evidence for various traditional uses. The present review on its botany, traditional uses, pharmacological activities and phytochemistry which provides preliminary information for further studies for this potential medicinal plant.

Pain is an unpleasant sensation and emotional experience linked to tissue damage. Pain occurs when something hurts, causing an unpleasant or uncomfortable feeling. The nearness of pain implies that something isn't right. Each individual is the best judge own pain. Pain of any origin comprises an individual's life.

The analgesic activity of SRE was assessed by employing different Materials and Methods: pain models such as, i) hot plate and tail flick tests for central analgesia.
\end{abstract}

KEYWORDS: Hot Plate, Resin, Shorea Robusta, Tail Flick. 


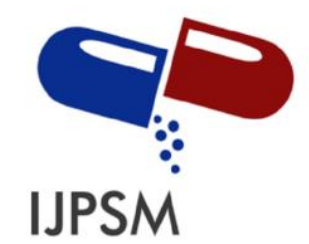

Chourasiya Vaibhav et al, Int. Journal of Pharmaceutical Sciences and Medicine (IJPSM), Vol.6 Issue. 8, August- 2021, pg. 118-133

ISSN: 2519-9889

Impact Factor: 3.426

1. INTRODUCTION: Shorea robusta (Sal) belongs to the family Dipterocarpaceae (twowinged fruit), which is most commonly found in Indonesia, but can also be seen in Malaysia, the Philippines and certain parts of Northern India. The various parts of the plant are traditionally used in India for the treatment of diverse ailments. The leaves are used to treat wounds, ulcers, itching, leprosy, gonorrhea, cough, earache and headache. The oleoresin exuded from the cut bark has astringent and detergent properties. In Unani medicine, the resin is used for treating menorrhagia, enlargement of the spleen and for relieving eye irritations. In Ayurveda, the leaves are used as anthelmintic and alexiteric. The powdered stem, bark or bark paste is applied to stop

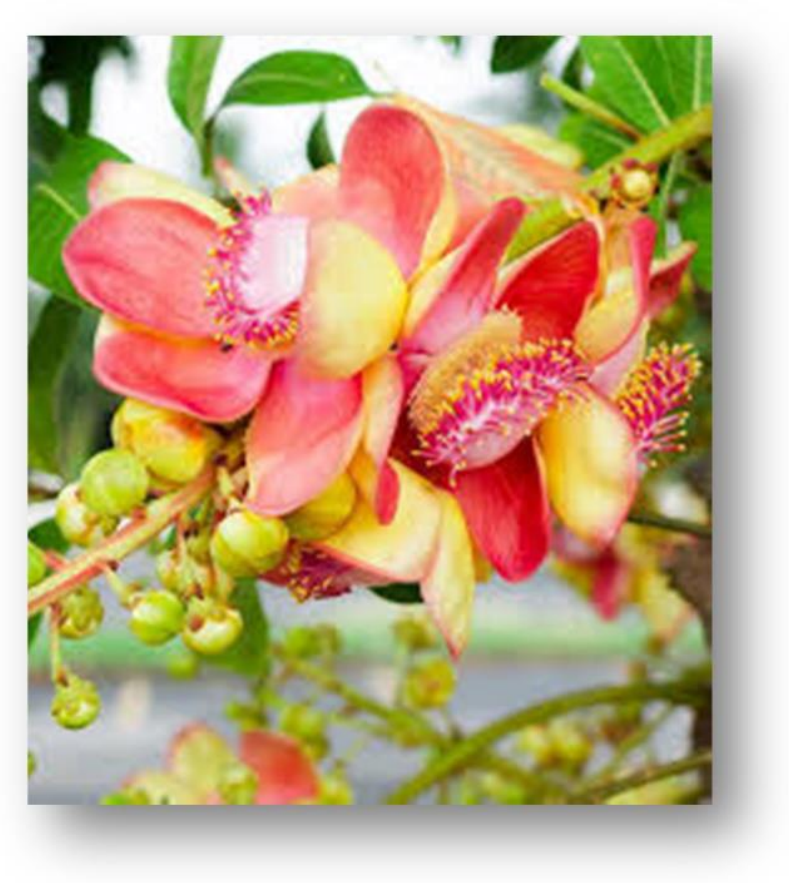
bleeding and promote healing of cuts among the tribal inhabitants of southern Bihar and the Kondhs of south-western Odisha, India.[1] The resin obtained from the plant is considered as an astringent and a detergent and is used with honey or sugar in dysentery and bleeding piles and also for fumigating the rooms of ill people. It is also given in gonorrhea and for weak digestion. Its bark decoction is used as drops for ear problems and the fruits for diarrhea.[2] S. robusta leaf extract was found to possess significant analgesic activity[3] and its resin along with some other constituents has also shown potential in wound healing.[4] In view of the importance of medicinal plants as a potential source of cheaper, safer and effective remedies for treating diseases in animals, and the traditional use of S. robusta resin (SRE) in various disorders, the present study was undertaken with special emphasis on the study of the analgesic effects of its alcoholic extract. 


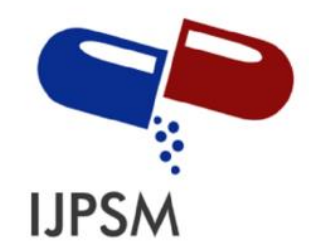

Chourasiya Vaibhav et al, Int. Journal of Pharmaceutical Sciences and Medicine (IJPSM), Vol.6 Issue. 8, August- 2021, pg. 118-133

ISSN: 2519-9889

Impact Factor: 3.426

1.1 TAXONOMY AND MORPHOLOGY: Shorea robusta is a large, deciduous tree up to $50 \mathrm{~m}$ tall and with a dbh of $5 \mathrm{~m}$; these are exceptional sizes, and under normal conditions S. robusta trees attain a height of about 18-32 m and girths of 1.5-2 m; bole is clean, straight and cylindrical, but often bearing epicormic branches; crown is spreading and spherical. Bark dark brown and thick, with longitudinal fissures deep in poles, becoming shallow in mature trees; provides effective protection against fire. The tree develops a long taproot at a very young age. Leaves simple, shiny, glabrous, about $10-25 \mathrm{~cm}$ long and broadly oval at the base, with the apex tapering into a long point; new leaves reddish, soon becoming delicate green. Flowers yellowish-white, arranged in large terminal or axillary racemose panicles. Fruit at full size about $1.3-1.5 \mathrm{~cm}$ long and $1 \mathrm{~cm}$ in diameter; it is surrounded by segments of the calyx enlarged into 5 rather unequal wings about $5-7.5 \mathrm{~cm}$ long.

1.2 DISTRIBUTION: Shorea robusta is widely distributed in India, Nepal and Bhutan. In India, the species is distributed from Himachal Pradesh to Assam, Tripura, West Bengal, Bihar and Orissa, Eastern districts of Madhya Pradesh extending further to the Eastern Ghats of Andhra Pradesh 18,19; and it is dominantly distributed on the plains and lower foothills of the Himalayas and also along the valleys20 . S. robusta propogates naturally through seed and coppice. Direct sowing is the cheapest and best method of artificial propagation, although stump plantings, planting out entire plants with balls of earth, and planting out container-grown seedlings are also employed ${ }^{21}$.

\subsection{TAXONOMY : Kingdom : Plantae \\ Unranked : Angiosperms \\ Unranked : Eudicots}




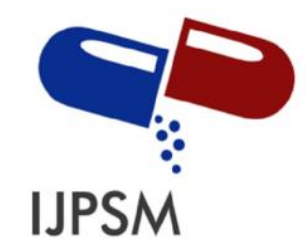

Chourasiya Vaibhav et al, Int. Journal of Pharmaceutical Sciences and Medicine (IJPSM), Vol.6 Issue. 8, August- 2021, pg. 118-133

ISSN: 2519-9889

Impact Factor: 3.426

$\begin{array}{lll}\text { Unranked } & \text { : } & \text { Rosids } \\ \text { Order } & \text { : } & \text { Malvales } \\ \text { Family } & \text { : } & \text { Dipterocarpaceae } \\ \text { Genus } & \text { : } & \text { Shorea } \\ \text { Species } & \text { : } & \text { Shorea robusta }\end{array}$

1.4 PHYTOCHEMICALS : S. robusta contain ursolic acid and $\alpha$-amyrenone; $\alpha$ and $\beta$ amyrin,[13] bark contains ursonic acid and oleanane, Shoreaphenol ${ }^{14}$ isolated from bark of S. robusta seed contains hopeaphenol, leucoanthocyanidin, and 3,7-dihydroxy8methoxyflavone7-O- $\alpha$-l-rhamnopyranosyl-( $1 \rightarrow 4)-\alpha$-1-rhamnonopyrano-syl $(1 \rightarrow 6)-\beta$ dglucopyranoside $;{ }^{15}$ while heartwood contains germacrene-D. ${ }^{8}$ The isolation of $\beta$-amyrin, friedelin, $\beta$-sitosterol, pheophytin- $\alpha$, and dihydroxyisoflavone from mature leaves are also report.

\subsection{PHARMACOLOGICAL ACTIVITY:}

\begin{tabular}{|c|c|}
\hline Vernacular names & $\begin{array}{l}\text { Region/language/system } \\
\text { of medicine }\end{array}$ \\
\hline Sakhu, sal, shal, Śakher, Salwa & Bengali \\
\hline Borsal, hal, sakhu, sakhwa, sal, shal & Hindi \\
\hline Kungiliyam, Attam, Shalam & Tamil \\
\hline Salbaum, Salharzbaum & German \\
\hline Agrakh, sakhua, sakwa, sal & Nepali \\
\hline Damar de l'Inde, Arbre à Sal, Balau Jaune, & French \\
\hline Sal & Assamese \\
\hline Enkhyen & Burmese \\
\hline Suo Luo Shuang, Suo Luo Shuang Shu & Chinese \\
\hline Sal Tree, Common Sal, Indian Dammer, Sal Seeds, Saltree, Yellow Balau & English \\
\hline Ral & Gujarati \\
\hline Jall, sal, salwa, shal & India \\
\hline Sara Noki, Serangan Batsuu, Shara Noki & Japanese \\
\hline Bangkirai (Borneo), Damar Laut (Indonesia), Selangan Batu (Sabah), Selangan Batu Kumus & Malay \\
\hline Guggilu, Rala & Marathi \\
\hline Sagua, Sal, Salwa, Sekwa & Oriya \\
\hline Sal, Seral (Resin) & Punjabi \\
\hline Sal, Salovoe Derevo, Shoreia Moshchnaia & Russian \\
\hline Ashvakarna, Chiraparna, Sal, Sala, Sarja & Sanskrit \\
\hline Dammala & Sinhalese \\
\hline Gugal, Guggilamu (Resin), Saluva, Sarjmu & Telugu \\
\hline Raal & Urdu \\
\hline Shala & Ayurveda \\
\hline
\end{tabular}




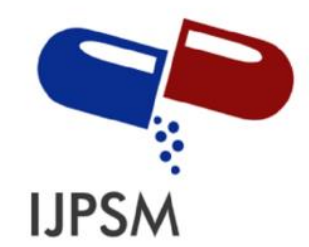

Chourasiya Vaibhav et al, Int. Journal of Pharmaceutical Sciences and Medicine (IJPSM), Vol.6 Issue. 8, August- 2021, pg. 118-133

ISSN: 2519-9889

Impact Factor: 3.426

1.5.1 ANALGESIC ACTIVITY: A 70\% ethanol extract of the dried powder resin of Shorea robusta was investigated for analgesic activity. The extract (30, 100 and $300 \mathrm{mg} / \mathrm{kg}$, i.p.) produced significant central and peripheral analgesic effect, as is evidenced from increase in reaction time in hot plate and tail flick tests. These results demonstrated that the extracts of S. robusta possess significant analgesic properties ${ }^{23}$. The methanolic and aqueous leaf extract of S. robusta shows analgesic activity with acetic-acid induced writhing and tail flick tests. The dose of both extracts such as methanol and aqueous extract (200 and 400mg/kg i.p.) caused significant reduction of writhing and tail flick method in rats and mice by different ways.

1.5.2 ANTIPYRETIC ACTIVITY: The ethanolic extract (70\%) of S. robusta resin (SRE) was investigated for its antipyretic activities. The antipyretic activity of SRE was studied using Brewer's yeast-induced pyrexia in rats. The rats were divided into five groups with five animals in each group. Group I was treated with vehicle i.e. 1\% v/v Tween-80 and served as control. Groups II to IV were treated with three different doses of SRE $(30,100$ and $300 \mathrm{mg} / \mathrm{kg}$ orally). Group V was treated with standard drug etoricoxib (10 mg/kg orally). The results of this study demonstrated antipyretic activities of S. robusta resin and supported its traditional therapeutic use in fever.

\subsubsection{ANTI-INFLAMMATORY ACTIVITY: The aqueous extract of leaves of} Shorea robusta with a dose of $100,200 \& 500 \mu \mathrm{g} / \mathrm{ml}$, was taken for the activity $\&$ compared with the standard Diclofenac doses of $20 \& 40 \mu \mathrm{g} / \mathrm{ml}$, in HRBC membrane stabilization model and same dose of extract was taken for activity \& compared with Aspirin $200 \mu \mathrm{g} / \mathrm{ml}$, using Heat Induced Haemolytic method. The extract of $500 \mu \mathrm{g} / \mathrm{ml}$ showed good result in both models 33 . The methanolic and aqueous leaf extract of S. robusta shows anti-inflammatory activity in carraganeen and dextran induced paw method and cotton-pelletinduced granuloma model. The dose of both extracts such as methanol and aqueous extract (200 and 400mg/kg i.p and p.o.) caused significant effect in rats and mice by different ways. 


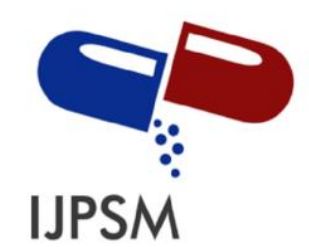

Chourasiya Vaibhav et al, Int. Journal of Pharmaceutical Sciences and Medicine (IJPSM), Vol.6 Issue. 8, August- 2021, pg. 118-133

ISSN: 2519-9889

Impact Factor: 3.426

1.5.4 ANTINOCICEPTIVE ACTIVITY: A methanol extract of the dried leaves of Shorea robusta was investigated for antinociceptive activity. The extract (200 and $400 \mathrm{mg} / \mathrm{kg}$, p.o) produced a dose dependent antinociceptive effect was also observed with hotplate device maintained at 550C, Acetic acid induced writhing, formaline induced paw licking, Tail clip and Tail flick models in mice. Two different dose levels exhibited a significant anti-nociceptive activity in different animal models of pain. In hot plate test, actinociceptive reaction towards thermal stimuli in mice is a well validated model for detection of opiate like analgesic drugs wherein pain response is from spinal origin 9 .

1.5.5 ANTIBACTERIAL ACTIVITY: The aqueous extract of floral parts of Shorea robusta was prepared with cold water maceration. Well diffusion method was employed to determine the effect of antibacterial potential against Gram positive bacteria viz. Staphylococcus aureus and Bacillus subtilis and Gram negative bacteria viz. Klebsiella pneumoniae and Serratia marcescens. Aqueous extract of the plant has showed significant inhibitory activity on different bacterial species tested against penicillin as standard antibacterial agent. Furthermore, the preliminary phytochemical analysis revealed that the aqueous extract possesses tannins, flavanoids, cardiac glycosides and steroids, which are involved in antibacterial activity.

1.5.6 ANTI-OBESITY ACTIVITY: Anti-obesity effect of hydro-alcoholic extract of Shorea robusta (HASR) leaves on monosodium glutamate induced obesity in albino rats. Monosodium glutamate is used to induce obesity for 7 days along with normal diet and obtained obese rats were treated with Shorea robusta in a dose of 200,400 and $600 \mathrm{mg} / \mathrm{kg}$ p.o for next 41days. Physical parameters such as body weight, various organs and adipose tissue weight and various biochemical parameters like serum glucose, triglyceride, cholesterol, LDL-C, HDL-C, VLDL-C, atherogenic index, SGPT and SGOT were evaluated and compared with both normal control and obesity control groups. From result, it was concluded that hydro-alcoholic Shorea robusta leaves extract is a potential drug which can be used for treatment of obesity and favours the correction of disturbed lipid profile. 


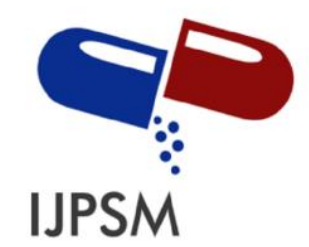

Chourasiya Vaibhav et al, Int. Journal of Pharmaceutical Sciences and Medicine (IJPSM), Vol.6 Issue. 8, August- 2021, pg. 118-133

ISSN: 2519-9889

Impact Factor: 3.426

1.5.7 ANTIULCER ACTIVITY: Gastroprotective potential of S. robusta resin (dissolved in water) at two different doses (150 and $300 \mathrm{mg} / \mathrm{kg}$ bw p.o.) was studied on ethanol and pyloric ligation (PL) induced gastric ulcer models in rats. Pretreatment with the resin (SRR) produced $62.69 \%$ inhibition of gastric mucosal damage in ethanol induced model and $64.55 \%$ inhibition in PL-induced model which was comparable to the reference drug omeprazole.

1.5.8 ANTIMICROBIAL ACTIVITY: The aqueous, methanol, petroleum and benzene extract of oleoresin of Shorea robusta were tested. Different extracts inhibited the growth of used microorganisms. Aqueous extracts of Shorea robusta exhibits significant activity against Bacillus coagulans, Escherichia coli, Bacillus cereus and moderate inhibition on Salmonella typhi and Bacillus subtilis and less activity against Proteus vulgaris and Pseudomonas fluorescence. However, ethanolic extracts also exhibited significant activity against Staphylococcus aureus, S. epidermidis and Escherichia coli, moderate inhibition on Candida albicans and Bacillus coagulans. The results revealed methanol extract showed more significant activity. The petroleum ether and benzene extracts showed less inhibitory activity when compared with the above two extracts. The Petroleum ether showed activity against Escherichia coli, Aspergillus flavus and Candida albicans and whereas benzene extracts worked against Bacillus licheniformis, Bacillus cereus and Aspergillus flavus. It may be concluded that Shorea robusta resin have a stronger and broader spectrum of antimicrobial activity against a number of pathogenic microorganisms 18 .

1.5.9 IMMUNOMODULATORY ACTIVITY: The ethanolic extract of Shorea robusta bark was administered p.o. (orally) to mice at a dose of $100 \mathrm{mg}$ and $300 \mathrm{mg} / \mathrm{kg}$ body weight per day for 14 days. In this study, Shorea robusta bark extract administrated rat models at $300 \mathrm{mg} / \mathrm{kg}$ per day, i.p showed significant effect in stimulating immunomodulatory response, thus Shorea robusta bark is an effective natural health product for modulating immune system ${ }^{39}$.

1.5.10 KAIROMONAL ACTIVITY: The attractant (kairomonal) property of some compounds isolated from bark of sal (Shorea robusta) against its dreaded pest sal borer, 


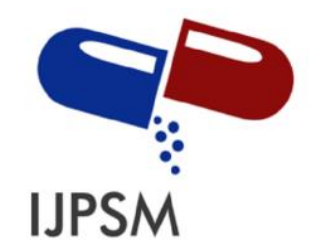

Chourasiya Vaibhav et al, Int. Journal of Pharmaceutical Sciences and Medicine (IJPSM), Vol.6 Issue. 8, August- 2021, pg. 118-133

ISSN: 2519-9889

Impact Factor: 3.426

Hoplocerambyx spinicornis, in laboratory. Extract of the bark and its various isolates were prepared by standard procedure and subjected to bioassay. Behaviour exhibited by the beetles, viz., orientations, walking movement, antennal activity, visits to the test compound treated surface, biting and feeding attempts to the particular compound and number of beetles attracted has been recorded. They showed positive behaviour with regard to the parameters discussed above against the bark extract as well as other isolated compounds. The chemical analysis of the compounds exhibiting the kairomonal property has also been performed ${ }^{40}$.

\subsubsection{FREE-RADICAL SCAVENGING AND ANTIOXIDANT} ACTIVITIES: Antioxidants are one of the key players in tumorigenesis, several natural and synthetic antioxidants were shown to have anticancer effects. The aim of the present study is to divulge the preventive nature of Shorea robusta bark extract (SRBE) during diethylnitrosamine (DEN)-induced liver cancer in male Wistar albino rats. Administration of DEN to rats resulted in increased serum marker enzymes aspartate transaminase (AST), alanine transaminase (ALT), lactate dehydrogenase (LDH), and gamma glutamyl transpeptidase (GGT). The levels of lipid peroxides elevated with subsequent decrease in the tissue antioxidants like superoxide dismutase (SOD), catalase (CAT), reduced glutathione (GSH), glutathione peroxidase (GPx), and glutathione reductase (GR). SRBE supplementation $(500 \mathrm{mg} / \mathrm{kg}$ body weight) significantly attenuated these alterations, thereby showing potent anticancer effect in liver cancer. These findings suggest that SRBE prevents lipid peroxidation, hepatic cell damage, and protects the antioxidant system in DENinduced hepatocellular carcinogenesis ${ }^{41}$.

1.5.12 WOUNDHEALING ACTIVITY : The ethanolic extract of S. robusta (10 and 30 $\% \mathrm{w} / \mathrm{w}$ ) applied locally in excised and incised wounds) produced a dose-dependent acceleration in wound contraction and increased hydroxypyroline content and tensile strength of wound in rats. The result demonstrate wound healing activity of ethanolic extract of S. robusta resin ${ }^{22}$. 


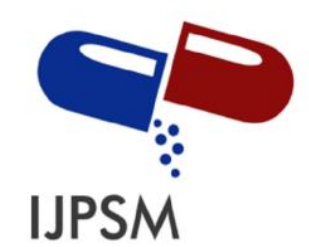

Chourasiya Vaibhav et al, Int. Journal of Pharmaceutical Sciences and Medicine (IJPSM), Vol.6 Issue. 8, August- 2021, pg. 118-133

ISSN: 2519-9889

Impact Factor: 3.426

\section{MATERIALS AND METHODS}

2.1 PLANT MATERIAL: Resins of Shorea Robusta were collected from Dharnaka Mhow, Indore (M.P.) India.

2.2 TREATMENT OF PLANT PART: The resins of the plant were cleaned, dried under shade and powdered by a mechanical grinder.

2.3PREPARATION OF ETHANOLIC EXTRACT: Coarsely powdered resins was extracted using soxhlet apparatus with petroleum ether (for defeating). After drying, the residue was extracted with methanol and was filtered. The methanolic solution (filtrate) was evaporated to dryness to get methanolic extract. The methanolic extract obtained was screened for phytochemical analysis.

2.4PHYTOCHEMICAL TESTS: For the phytochemical investigation, 1\% of aqueous extract of each extract was used following methods for phytochemical screenings were applied on extract.

\section{a) Carbohydrates}

Fehling's test; $1 \mathrm{ml}$ Fehling's A solution and $1 \mathrm{ml}$ Fehling's B solution were mixed and boiled it for 1 minute. Now the equal volume of test solution was added to above mixture. The solution was heated in water bath for 5-10 minutes. First yellow and then brick red precipitate was obtained. This confirmed the presence of sugar. 


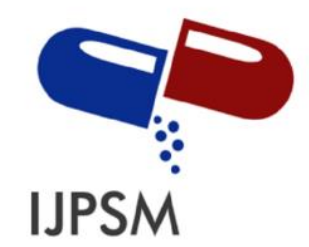

Chourasiya Vaibhav et al, Int. Journal of Pharmaceutical Sciences and Medicine (IJPSM), Vol.6 Issue. 8, August- 2021, pg. 118-133

ISSN: 2519-9889

Impact Factor: 3.426

\section{b) Flavone Glycosides}

Molisch test; $2 \mathrm{ml}$ of test solution is placed in test tube. 2 drops of Molisch reagent (a solution of $\alpha$-napthol in $95 \%$ ethanol) was added. The solution was poured slowly into a tube which contained $2 \mathrm{ml}$ of sulphuric acid then two layers was formed. There was formation of purple product at the interface of the two layers.

\section{c) Flavonoids}

On addition of an increasing amount of sodium hydroxide, the extract was shown yellow coloration; this was decolorized after addition of dilute hydrochloric acid.

\section{d) Steroids and Triterpenoids}

Salkowski Test; Treat the extract with few drops of concentrated sulphuric acid, red color at lower layer indicates presence of steroid and formation of yellow color lower layer indicates presence of Triterpenoids.

e) Alkaloids

Mayer's test: To $2 \mathrm{ml}$ of palnt extract, $2 \mathrm{ml}$ of concentrated hydrochloric acid was added. Then, few drops of mayer's reagent were added. The presence of green or white precipitate indicated the presence of alkaloids.

\section{f) Tannins and Phenols}

Ferric chloride Test: To $3 \mathrm{ml}$ of extract, $3 \mathrm{ml}$ of $5 \% \mathrm{w} / \mathrm{v}$ ferric chloride solution was added. The blue - black color indicates the presence of tannins and phenols.

\section{g) Test For Saponins}

Foam Test: The extract $(2 \mathrm{~g})$ was shaken vigorously with $20 \mathrm{ml}$ of water and observed for persistent foam, which indicates the presence of saponins. 


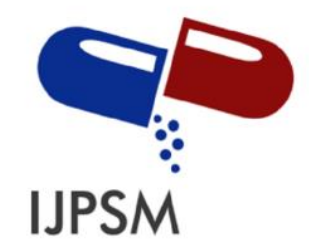

Chourasiya Vaibhav et al, Int. Journal of Pharmaceutical Sciences and Medicine (IJPSM), Vol.6 Issue. 8, August- 2021, pg. 118-133

ISSN: 2519-9889

Impact Factor: 3.426

3 EXPERIMENTAL ANIMAL: Healthy Wistar albino rats (150-250 g)/Swiss mice (18- $20 \mathrm{~g}$ ) of approximately the same age were used for the study. They were grouped into 5 groups of 6 animals each into a clean polypropylene cage and were maintained on a balanced ration obtained from the Feed Technology Unit of the Institute. Fresh drinking water was offered to the animals daily ad libitum. The experiments were carried out in accordance with the guidelines of Animal Ethics Committee, IVRI, Izatnagar.

\subsection{METHODS:}

3.1.1 EDDY'S HOT PLATE: The hot plate test Eddy and Leimbach (1953) is a simple behavioral screen used for estimating the effects of NCEs on the threshold for detecting pain. It

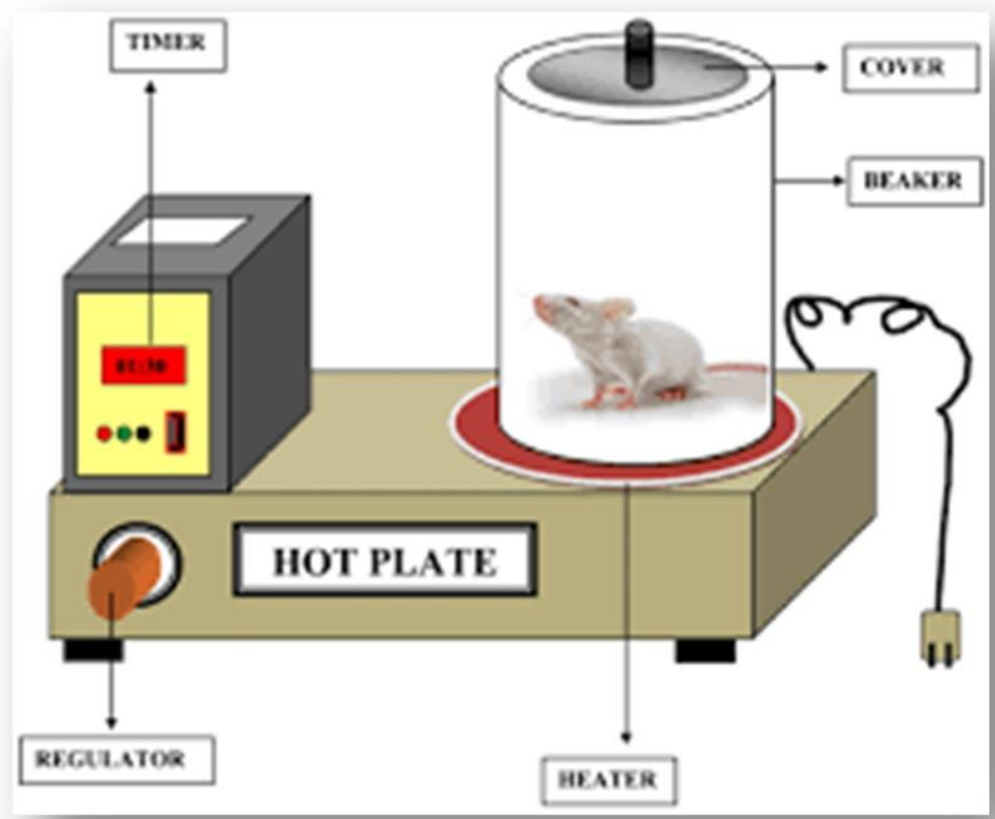

is based on the principle that when rodents are placed onto a hot surface they will initially demonstrate the aversive effects of the thermal stimulus by licking their paws and, ultimately, by overt attempts to escape the environment (jumping). Substances that alter nociceptive threshold either increase the latency to licking/jumping (analgesic effect) or decrease it (hyperalgesic effect).

Analgesics such as those with an antiinflammatory profile, including aspirin, paracetamol, and ibuprofen, are less active in this test than are more powerful analgesics such as opioids. 


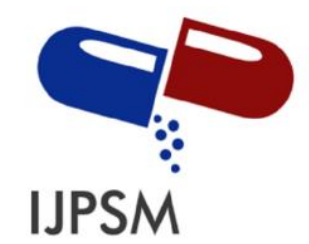

Chourasiya Vaibhav et al, Int. Journal of Pharmaceutical Sciences and Medicine (IJPSM), Vol.6 Issue. 8, August- 2021, pg. 118-133

ISSN: 2519-9889

Impact Factor: 3.426

3.2.2 LIGHT AND DARK MODEL : The tail flick test, first described in 1941, involves application of a heat stimulus to the tail of mice and rats, and the time taken for the tail to "flick" or twitch is recorded. The heat stimulus applied can be radiant heat, where a focused beam of light is applied to the tail, or hot water, where the distal end of the tail is immersed into a water bath set at a constant temperature between $46^{\circ} \mathrm{C}$ and $52^{\circ} \mathrm{C}$, with the latter requiring no specialized equipment. Both versions of the test require the animal to be loosely restrained. (A) Tail flick test (radiant heat). Rodents are restrained and a focused beam of light is applied to tail. The time taken to "flick" or withdraw the tail from the heat stimulus is recorded. (B) Hot plate test. In the conventional hot plate test the rodent is placed on a metal surface maintained at a constant temperature (in this case $54^{\circ} \mathrm{C}$ ) and the time taken to elicit a nocifensive behavior (e.g., hind paw withdrawal or licking) is recorded. (C) Hargreaves test.

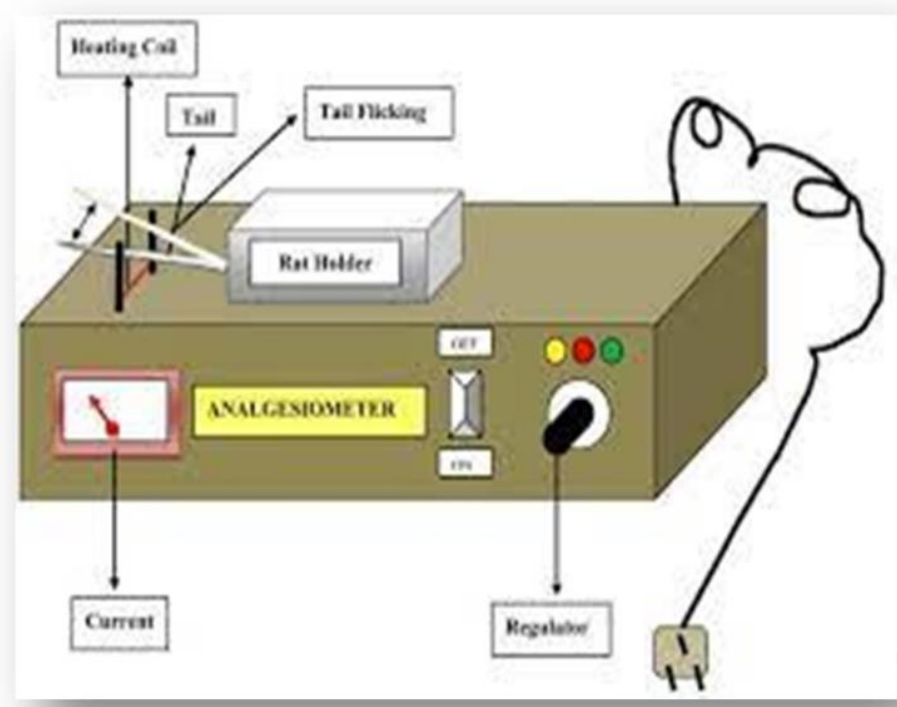

Rodents are placed individually in small enclosures with a glass floor. A radiant or infrared heat source is focused on the plantar surface of the hind paw and the time taken to withdraw from the heat stimulus is recorded. (D) Thermal probe test. Mice are placed individually in small cages with a barred floor. A small metal probe is applied to the hind paw, and heating is triggered by rotation of the handheld device until the mouse withdraws the paw. The device automatically records the temperature that paw withdrawal occurred (in this case $50^{\circ} \mathrm{C}$ ). 


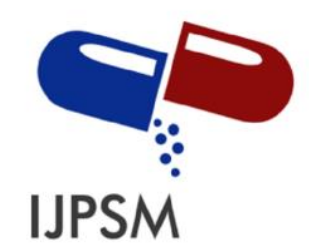

Chourasiya Vaibhav et al, Int. Journal of Pharmaceutical Sciences and Medicine (IJPSM), Vol.6 Issue. 8, August- 2021, pg. 118-133

ISSN: 2519-9889

Impact Factor: 3.426

4 CONCLUSION: The available scientific research on S. robusta has shown that it is an important medicinal plant used in a wide range of medical treatments. The plant has been in use for a long period of time without any documented serious adverse effects. The detailed information presented in this review provides evidence for its phytochemical, pharmacological \& traditional uses. The outcomes of such future studies will provide promising sources of phytochemicals that will have huge potential for the pharmaceutical industry. So as per the current study, it is finding that S. robusta resin is extracted using different solvents. Most of the previous studies were performed using a formulation with different wax as a base.

\section{REFERENCES}

1. Kapoor RT. Indigenous utilization and potential of medicinal plants in the Phulpur tehsil of Allahabad district, India. Res J Med Plant 2012; 6: 225-235.

2. Attrey DP, Singh AK, Katyal J, Naved T. Pharmacognostical characterization \& preliminary Phytochemical investigation of seabuckthorn ( Hippophae rhamnoides L.) leaves. Indo Global J Pharma Sci 2012; 2(2): 108-113.

3. Sharma A, Shanker C, Tyagi LK, Singh M, Rao CV. Herbal medicine for market potential in India: An overview. Acad J Plant Sci 2008; 1: 26-36.

4. Kumar T, Chandrashekar KS. Bauhinia purpurea Linn: A Review of its ethnobotany, phytochemical and pharmacological profile. Res J Med Plant 2011; 5: 420-431.

5. Abdel-Azim NS, Khaled AS, Abdel Aaty AS, Moustafa MEM, Shams II, Faiza MH. Egyptian Herbal Drug Industry: Challenges and Future Prospects. Res J Med Plant 2011; 5: 136- 144.

6. Hegazy RA, Molari G, El-Sheikha AM. Prototype of Harvesting System for Some Aromatic and Medical Plants. Int J Agri Res 2011; 6: 420-428.

7. Sati SC, Sati N, Rawat U, Sati OP. Medicinal plants as a source of antioxidants. Res J Phytochem 2010; 4: 213-224.

8. Dev S. Ancient-modern concordance in Ayurvedic plants: some examples. Environmental Health () 2021, IJPSM All Rights Reserved, www.ijpsm.com 


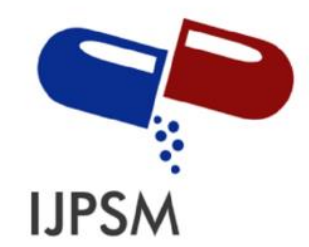

Chourasiya Vaibhav et al, Int. Journal of Pharmaceutical Sciences and Medicine (IJPSM), Vol.6 Issue. 8, August- 2021, pg. 118-133

ISSN: 2519-9889

Impact Factor: 3.426

Perspectives 1999; 107: 783-789.

9. Balasundaram A, Kumari P, John G, Selvakumar BN. Antimicrobial activity of the leaf extracts of two medicinal plants against MRSA (Methicilin Resistant Staphylococcus aureus) from human urinary tract pathogens. Res J Microbiol 2011; 6: 625-631.

10. Tomar A. Folk medicinal uses of plant roots from Meerut district, Uttar Pradesh. Indian J Trad Knowled 2009; 8: 298- 301.

11. Alluri VK, Tayi VNR, Sundararaju D, Vanisree M, Hsin- Sheng T, Subbaraju GV. Assessment of bioactivity of Indian medicinal plants using brine shrimp (Artemia saina) lethality assay. Int J Appl Sci Enginee 2005; 2: 125-134.

12. Chattopadhyay D, Mukherjee H, Bag P, Ojha D, Konreddy AK, Dutta S et al. Inhibition of NO2, PGE2, TNF- $\alpha$, and iNOS expression by Shorea robusta L.: An ethnomedicine used for antiinflammatory and analgesic activity. Evid Based Complement Alternat Med 2012; 1-14.

13. Khare CP. Indian Medicinal Plant. Springer Science and Business Media Publisher, 2007: 428.

14. Orwa C, Mutua A, Kindt R, Jamnadass R, Simons A. Agroforestree Database : a tree reference and selection guide version 4.0 (http://www.worldagroforestry.org/af/treedb/) (2009).

15. Joshi N, Sharma K. Taxonomy and ecological features of Dioscorea L. (Dioscoreaceae) in Nepal. Jour Dept Pl Res N. 35 2013; 1-8.

16. Timilsina N, Ross MS, Heinen JT. A community analysis of sal (Shorea robusta) forests in the western Terai of Nepal. For Ecol Manage 2007; 241: 223-234.

17. Pandey SK, Shukla RP. Regeneration strategy and plant diversity status in degraded sal forests. Curr Sci 2001; 81: 95- 102.

18. Murthy KSR, Lakshmi N, Ramulu DR. Biological activity and phytochemical screening of the oleoresin of Shorea robusta Gaertn. f. Trop Subtrop Agroeco 2011; 14: 787-791.

19. Chitale VS, Behera MD. Can the distribution of sal (Shorea robusta Gaertn. f.) shift in the Northeastern direction in India due to changing climate? Curr Sci 2012; 102(8): 1126-1135.

20. Gautam MK, Tripathi AK, Manhas RK. Assessment of critical loads in tropical sal (Shorea robusta Gaertn. f.) forests of Doon Valley Himalayas, India. Water Air Soil Pollut 2011; 218: 


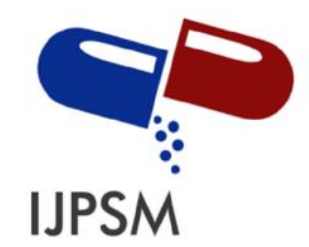

Chourasiya Vaibhav et al, Int. Journal of Pharmaceutical Sciences and Medicine (IJPSM), Vol.6 Issue. 8, August- 2021, pg. 118-133

ISSN: 2519-9889

Impact Factor: 3.426

235- 264.

21. Pradhann P, Dutta AK, Roy A, Basu SK, Acharya K. Inventory and spatial ecology of macrofungi in the Shorea robusta forest ecosystem of lateritic region of West Bengal. Biodiver 2012; 13(2): 88-99.

22. Wani TA, Chandrashekara HH, Kumar D, Prasad R, Gopal A, Sardar KK, et al. Wound healing activity of ethanolic extract of Shorea robusta Gaertn, f. resin. Indian J Exp Biol 2012; 50: 277 281.

23. Wani TA, Kumar D, Prasad R, Verma PK, Sardar KK, Tandan SK, et al. Analgesic activity of the ethanolic extract of Shorea robusta resin in experimental animals. Indian J pharmacol 2012; 44: 493-499.

24. Kaur S, Dayal R, Varshney VK, Bartley JP. GC-MS analysis of essential oils of heartwood and resin of Shorea robusta. Planta Med 2001; 67(9): 883-886.

25. Shafiuddin Md, Khan A, Ali S. Wound healing activity of traditional herbal formulation. Int J Chem Sci 2009; 7(2): 639- 664.

26. Dey A, Gupta B, Nath JD. Traditional phytotherapy against skin diseases and in wound healing of the tribes of Purulia district,West Bengal, India. J Med Plants Res 2012; 6(33): 4825-4831.

27. Hota RK, Bapuji M. Triterpenoids from the resin of Shorea robusta. Phytochem 1993; 32(2): 466-468.

28. Mishra LN, Ahmed A. Triterpenoids from Shorea robusta resin. Phytochem 1997; 45(3): 575578.

29. Harbone JB. Recent advances in chemical ecology. Nat Prod Rep 1999; 16(4): 509-523.

30. Patra A, Dey AK, Kundu AB. Shoreaphenol, a polyphenol from Shorea robusta. Phytochem 1992; 37(7): 2561-2562.

31. Prakash EO, Rao JT. A new flavone glycoside from the seeds of Shorea robusta. Fitoter 1999; 70(6): 539-541.

32. Chauhan SMS, Singh M, Narayan L. Isolation of 3ßhydroxyolean-12-ene, friedelin and 7methoxy-4_-5- dihydroxyisoflavone from dry and fresh leaves of Shorea robusta. Indian J Chem 


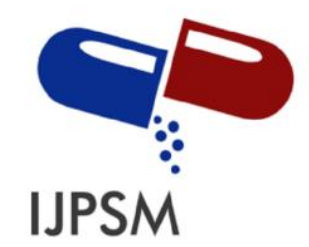

Chourasiya Vaibhav et al, Int. Journal of Pharmaceutical Sciences and Medicine (IJPSM), Vol.6 Issue. 8, August- 2021, pg. 118-133

ISSN: 2519-9889

Impact Factor: 3.426

Sec B 2002; 41(5): 1097-1099.

33. Nainwal P, Bhatt R, Nanda D, Saini P. Screening of in vitro anti-inflammatory activity of aqueous extract of leaves of Shorea robusta. Int J Pharmacol Screen Method 2013; 3(2): 43-45.

34. Jyothi G, William MC, Kumar RB, Mohan KG. Antinociceptive and antiinflammatory activity of methanolic extract of leaves of Shorea robusta. Pharmacol 2008; 1: 9-19.

35. Wani TA, Chandrashekhara HH, Kumar D, Prasad R, Sardar KK, Tandan SK. Antiinflammatory and antipyretic activities of ethanolic extract of Shorea robusta Gaertn. f. resin. Indian J Biochem Biophy 2012; 49: 463-467.

36. Duddukuri GR, Rao DE, Kaladhar DSVGK, Sastry YN, Rao KK, Chaitanya KK, et al. Preliminary studies on in vitro antibacterial activity and phytochemical analysis of aqueous crude extract of Shorea robusta floral parts. Int J Curr Res 2011; 3(8): 21-23.

37. Supriya K, Kotagiri S, Swamy VBM, Swamy AP, Vishwanath KM. Anti-Obesity activity of Shorea robusta G. leaves extract on monosodium glutamate induced obesity in albino rats. Res J Pharma Biol Chem Sci 2012; 3(3): 555-565.

38. Muthu S, Nagarajan A, Palanisamy B. Antiulcerogenic effect of resin from Shorea robusta Gaertn. f. on experimentally induced ulcer models. Int J Pharm Pharm Sci 2013; 5(1): 269-272.

39. Kalaiselvan A, Gokulakrishnan K. Bark extract of Shorea robusta on modulation of immune response in rats. Int J Recent Scienti Res 2012; 3(8): 693 -697.

40. Kulkarni N, Tripathi S, Joshi KC. Kairomonal activity of compounds isolated from bark of Sal (Shorea robusta Gaert. f.) for attracting the sal heartwood borer, Hoplocerambyx spinicoris newman (Coleopteria: Cerambycidae). Int J Forest 2004; 27(3): 321-325.

41. Kalaiselvan A, Gokulakrishnan K, Anand T, Akhilesh U, Velavan S. Preventive effect of Shorea robusta bark extract against diethylnitrosamine induced hepatocellular carcinoma in rats. Int Res J Medical Sci 2013; 1(1): 2-9. [42] Singh B, Singh PR, Mohanty MK. Toxicity of a plant based mosquito repellent/killer. Interdiscip Toxicol 2012; 5(4): 184- 191. 